Check for updates

Cite this: RSC Adv., 2018, 8, 11598

Received 19th October 2017

Accepted 9th March 2018

DOI: $10.1039 / c 7 r a 11557 a$

rsc.li/rsc-advances

\section{Nonstoichiometric oxygen in Mn-Ga-O spinels: reduction features of the oxides and their catalytic activity}

O. A. Bulavchenko, D ${ }^{\star a b}$ O. S. Venediktova, ${ }^{a b}$ T. N. Afonasenko, ${ }^{c}$ P. G. Tsyrul'nikov, ${ }^{c}$ A. A. Saraev, (DD ${ }^{\text {ab }}$ V. V. Kaichev (D) ab and S. V. Tsybulya ${ }^{\text {ab }}$

\begin{abstract}
The subject of this study was the content of oxygen in mixed oxides with the spinel structure $\mathrm{Mn}_{1.7} \mathrm{Ga}_{1.3} \mathrm{O}_{4}$ that were synthesized by coprecipitation and thermal treatment in argon at $600-1200^{\circ} \mathrm{C}$. The study revealed the presence of excess oxygen in "low-temperature" oxides synthesized at $600-800{ }^{\circ} \mathrm{C}$. The occurrence of superstoichiometric oxygen in the structure of $\mathrm{Mn}_{1.7} \mathrm{Ga}_{1.3} \mathrm{O}_{4+\delta}$ oxide indicates the formation of cationic vacancies, which shows up as a decreased lattice parameter in comparison with "high-temperature" oxides synthesized at $1000-1200{ }^{\circ} \mathrm{C}$; the additional negative charge is compensated by an increased content of $\mathrm{Mn}^{3+}$ cations according to XPS. The low-temperature oxides containing excess oxygen show a higher catalytic activity in $\mathrm{CO}$ oxidation as compared to the high-temperature oxides, the reaction temperature was $275^{\circ} \mathrm{C}$. For oxides prepared at 600 and $800{ }^{\circ} \mathrm{C}$, catalytic activity was 0.0278 and $0.0048 \mathrm{~cm}^{3}$ (CO) per $\mathrm{g}$ per $\mathrm{s}$, and further increase in synthesis temperature leads to a drop in activity to zero. The process of oxygen loss by $\mathrm{Mn}_{1.7} \mathrm{Ga}_{1.3} \mathrm{O}_{4+\delta}$ was studied in detail by TPR, in situ XRD and XPS. It was found that the hydrogen reduction of $\mathrm{Mn}_{1.7} \mathrm{Ga}_{1.3} \mathrm{O}_{4+\delta}$ proceeds in two steps. In the first step, excess oxygen is removed, $\mathrm{Mn}_{1.7} \mathrm{Ga}_{1.3} \mathrm{O}_{4+\delta} \rightarrow \mathrm{Mn}_{1.7} \mathrm{Ga}_{1.3} \mathrm{O}_{4}$. In the second step, $\mathrm{Mn}^{3+}$ cations are reduced to $\mathrm{Mn}^{2+}$ in the spinel structure with a release of manganese oxide as a single crystal phase, $\mathrm{Mn}_{1.7} \mathrm{Ga}_{1.3} \mathrm{O}_{4} \rightarrow \mathrm{Mn}_{2} \mathrm{Ga}_{1} \mathrm{O}_{4}+\mathrm{MnO}$.
\end{abstract}

\section{Introduction}

The ability of manganese cations to change their oxidation state makes Mn-containing oxides efficient catalysts for various processes: oxidation of hydrocarbons, $\mathrm{CO}$, and $\mathrm{VOCs}^{\mathbf{1 - 6}}$ and the selective reduction of $\mathrm{NO}_{x}$ with $\mathrm{NH}_{3}{ }^{7}$

Of special interest are Mn-containing oxides with a spinel structure that possess a high thermal stability and are able to intercalate additional cations. The catalytic properties of $\mathrm{Mn}$ containing oxides were examined in different processes: $\mathrm{Mn}-$ Co oxides are promising for the oxidation of CO, propene, ${ }^{8}$ and benzyl alcohol, ${ }^{9}$ as materials for fuel cells and oxygen reduction/ evolution electrocatalysts; ${ }^{\mathbf{1 0 , 1 1}} \mathrm{Ga}-\mathrm{Co}-\mathrm{Mn}$ can be employed for visible-light-driven water oxidation; ${ }^{12} \mathrm{Mn}-\mathrm{Al}$ spinels are precursors of the active component of catalysts for the oxidation of $\mathrm{CO}$ and hydrocarbons; ${ }^{\mathbf{1 3}} \mathrm{Zn}-\mathrm{Mn}-\mathrm{Al}$ oxides are used for the reduction of nitrobenzene to nitroazobenzene; ${ }^{14}$ and $\mathrm{Mn}-\mathrm{Fe}$ as Fenton catalysts toward catalytic degradation of highly concentrated methylene blue..$^{15}$

\footnotetext{
${ }^{a}$ Boreskov Institute of Catalysis SB RAS, Lavrentieva Ave. 5, Novosibirsk, 630090, Russia.E-mail: isizy@catalysis.ru

${ }^{b}$ Novosibirsk State University, Pirogova Str. 2, Novosibirsk, 630090, Russia

${ }^{c}$ Institute of Hydrocarbons Processing SB RAS, Neftezavodskaya Str. 54, Omsk, 644040, Russia
}

The spinel structure is described by a general formula $\mathrm{AB}_{2} \mathrm{O}_{4}$, where $\mathrm{A}$ is a divalent cation, and $\mathrm{B}$ is a trivalent one. In a normal spinel, divalent cations A are located in tetrahedral positions, and trivalent cations B located in octahedral positions; however, in some compounds a partial or complete inversion may take place: divalent cation A resides in the octahedral position, while trivalent $\mathrm{B}$ in the tetrahedral one. Nonstoichiometry of the metal/oxygen ratio is commonly implemented in the spinel structure via the cationic vacancies with preservation of the closest oxygen packing, $\mathrm{A}_{1-x_{1}} \mathrm{~B}_{2-x_{2}}[]_{y} \mathrm{O}_{4}$; in this case, the chemical formula can be written as $\mathrm{AB}_{2} \mathrm{O}_{4+\delta}$, hence it follows that the structure includes superstoichiometric (excess) oxygen, which under certain conditions can pass to the gas phase and become reactive.

A relation between oxygen nonstoichiometry in $\mathrm{Mn}$ containing oxides with the spinel structure and their catalytic properties was investigated only in several works. In particular it was shown that the $\mathrm{Mn}^{3+}$ cation in $\mathrm{Zn}_{1-x} \mathrm{Mn}_{x} \mathrm{Al}_{2} \mathrm{O}_{4+\delta}(0<x<1)$ is the active site for reduction of nitrobenzene, ${ }^{\mathbf{1 6}}$ which may occur only in the case of partial inversion of spinel and appearance of cationic vacancies. ${ }^{\mathbf{1 4}}$ For $\mathrm{Mn}$-Co oxides, the activity in the oxidation of benzyl alcohol depends on the concentration of trivalent cations and, accordingly, on the oxygen content in the exposed planes and in the sub-layer. ${ }^{9}$

In this connection, it seems important to examine the effect of oxygen nonstoichiometry on the catalytic properties in 
oxidation reactions. On Mn-containing oxides, oxidation reactions are known to proceed through the Mars-van Krevelen mechanism, ${ }^{9}$ according to which in the first step lattice oxygen oxidizes the substrate which is accompanied by generation of an oxygen vacancy, and in the second step the reduced catalyst is reoxidized by gas-phase molecular oxygen. To investigate the effect of oxygen nonstoichiometry in Mn-containing oxides on the catalytic properties, we placed the manganese cation in the redox inert matrix of gallium oxide, which is able to form spinel structures. The oxidation of CO served as a model reaction. Previously, we investigated the conditions of formation of $\mathrm{Mn}$ $\mathrm{Ga}$ oxides in a wide range of $\mathrm{Mn} / \mathrm{Ga}$ cation ratio from 2 to 0.5 and calcination temperatures $600-1200{ }^{\circ} \mathrm{C} .{ }^{17}$ This paper considers in detail the redox properties of $\mathrm{Mn}-\mathrm{Ga}$ oxides with the spinel structure and the reduction of Mn cations in spinel by in situ XRD, XPS, and TPR, as well as the effect of excess oxygen on the activity in the oxidation of CO.

\section{Experimental}

\section{Preparation}

The calculated amount of $\mathrm{Ga}\left(\mathrm{NO}_{3}\right)_{3}$ and $\mathrm{Mn}\left(\mathrm{NO}_{3}\right)_{2}$ aqueous solutions was poured into a round-bottom flask. Precipitation was carried out under stirring with a gradual addition of a $5 \mathrm{M}$ $\mathrm{NH}_{4} \mathrm{OH}$ solution to bring the $\mathrm{pH}$ of the solution to 9. A mechanical stirrer rotated at $450 \mathrm{rpm}$. After a subsequent aging at $60{ }^{\circ} \mathrm{C}$ for $2 \mathrm{~h}$, the precipitate was filtered, washed with distilled water on a filter to $\mathrm{pH} 6$, and dried at $120^{\circ} \mathrm{C}$ for $2 \mathrm{~h}$.

The samples with $\mathrm{Mn}: \mathrm{Ga}=1.7: 1.3$ were calcined in an inert argon medium at $600,800,1000$, and $1200{ }^{\circ} \mathrm{C}$. Calcination was performed with a gas flow rate of $50-60 \mathrm{~mL} \mathrm{~min}^{-1}$ for $4 \mathrm{~h}$. This was followed by cooling in the inert medium at a rate of 10 $\mathrm{mL} \min ^{-1}$ until reaching the room temperature. A series of samples with $\mathrm{Mn}: \mathrm{Ga}=1.7: 1.3$ was chosen for further studies as the X-ray nearly single-phase for all temperatures. ${ }^{17}$

Simple oxides $\mathrm{Mn}_{2} \mathrm{O}_{3}$ and $\mathrm{Mn}_{3} \mathrm{O}_{4}$ were synthesized from $\mathrm{Mn}\left(\mathrm{NO}_{3}\right)_{2}$ by calcination at 650 and $1200{ }^{\circ} \mathrm{C}$ in air for $4 \mathrm{~h}$.

\section{XRD}

Powder X-ray diffraction was carried out using a Bruker D8 Advance Diffractometer (Germany) with the $\mathrm{CuK}_{\alpha}$ radiation $(\lambda=$ $1.5418 \AA$ ) in the $\theta / 2 \theta$ geometry. The diffractometer was equipped with a LynxEye linear semiconductor detector. A nickel filter was used to eliminate the $\mathrm{CuK}_{\beta}$ component. A $2 \theta$ range from 15 to $80^{\circ}$ was scanned using a step of $0.05^{\circ}$ and a counting time of $2 \mathrm{~s}$ at each point.

The diffraction data were interpreted using software programs and databases. In particular, the phase composition was determined with the use of PDF-4+ powder diffraction database. ${ }^{18}$ Sizes of coherent scattering region (CSR) were calculated by the Scherrer formula using 311 reflection of spinel. ${ }^{19}$

\section{In situ XRD}

In situ X-ray diffraction study was carried out under hydrogen reduction conditions on a D8 Advance diffractometer equipped with a reaction chamber XRK-900 (Anton Paar, Austria). The hydrogen flow rate was $40 \mathrm{~mL} \min ^{-1}$; and heating rate, $10^{\circ} \min ^{-1}$.

\section{XPS}

X-ray photoelectron spectroscopy was applied for the chemical analysis of the catalysts after reduction in hydrogen. XPS studies were performed on an X-ray photoelectron spectrometer (SPECS Surface Nano Analysis GmbH, Germany) equipped with a XR50M X-ray source with a twin $\mathrm{Al} / \mathrm{Ag}$ anode, a FOCUS-500 X-ray monochromator, a PHOIBOS-150 hemispherical electron energy analyzer, and a high-pressure cell. The core-level spectra were obtained using the monochromatic AlK $\alpha$ radiation $(h \nu=$ $1486.74 \mathrm{eV}$ ) under ultrahigh vacuum conditions. Charge correction was performed by setting the $\mathrm{Ga} 2 \mathrm{p}_{3 / 2}$ peak at $1117.9 \mathrm{eV}$. Relative element concentrations were determined from the integral intensities of XPS peaks using the crosssections according to Scofield. For a detailed analysis, the spectra were fitted into several peaks after the background subtraction by the Shirley method. The fitting procedure was performed using the CasaXPS software. ${ }^{20}$ The line shapes were approximated by the multiplication of Gaussian and Lorentzian functions.

The Mn-Ga sample synthesized at $600{ }^{\circ} \mathrm{C}$ was treated in the high-pressure cell by the following procedure. Loading of the sample, evacuation to ultrahigh vacuum $\left(10^{-7} \mathrm{mbar}\right)$, and admission of a gas (hydrogen, oxygen or argon, $\sim 1000$ Torr, cell volume $\sim 0.2 \mathrm{~L}$ ); heating to a specified temperature for $10 \mathrm{~min}$ and treatment at this temperature for $30 \mathrm{~min}$; evacuation of the cell and cooling to room temperature in a vacuum; recording of XP spectra.

\section{Catalytic tests}

Catalytic tests were performed in a flow regime in a glass reactor $170 \mathrm{~mm}$ in length and $10 \mathrm{~mm}$ in diameter. The initial gas mixture composition was $1 \% \mathrm{CO}, 2 \% \mathrm{O}_{2}, 8 \% \mathrm{~N}_{2}$, and $\mathrm{He}$ the rest. For changing the CO conversion, the flow rate of the gas mixture was varied in the range of $200-570 \mathrm{~mL} \mathrm{~min}^{-1}$. The oxidation of $\mathrm{CO}$ was carried out at $275{ }^{\circ} \mathrm{C}$. The reactant mixture before and after the reactor was analyzed by a chromatograph equipped with a packed column (zeolite $\mathrm{CaA}, 3 \mathrm{~m}$ ) and a thermal conductivity detector.

Catalytic activity was calculated from the CO conversion at different flow rates, taking into account the mass of the catalyst, according to the formula:

$$
\begin{gathered}
W(\mathrm{CO})=\left[C_{0}-C_{\text {cur }}\right] \times V /\left(60 \times m_{\text {cat }}\right),\left[\mathrm{cm}^{3}(\mathrm{CO}) \text { per g per s }\right] \\
C_{\text {cur }}=C_{0} \times\left(1-\left(P_{0}-P_{\text {cur }} / P_{0}\right)\right),
\end{gathered}
$$

where $P_{0}$ is the peak area corresponding to the initial concentration of $\mathrm{CO}$ in the reactant mixture; $P_{\text {cur }}$ is the peak area corresponding to the current concentration of $\mathrm{CO}$ at the reactor outlet; $C_{\text {cur }}$ is the current concentration of $\mathrm{CO}$ in the mixture, vol\%; $C_{0}$ is the initial concentration of $\mathrm{CO}$ in the mixture $\left(C_{0}=1 \mathrm{vol} \%\right) ; V$ is the feed rate of the reactant mixture, $\mathrm{mL} \min ^{-1}$; and $m_{\text {cat }}$ is the mass of a catalyst, $\mathrm{g}$. 
To compare the samples, their activities must be extrapolated to the same conversion of $\mathrm{CO}$ (in our case, 50\% conversion):

$$
W(\mathrm{CO})_{50 \%}=0.5 \times W / C_{\mathrm{cur}}^{\mathrm{av}},
$$

where

$$
C_{\mathrm{cur}}^{\mathrm{av}}=\left(C_{0}+C_{\mathrm{cur}}\right) / 2,(\%)
$$

Before the catalytic tests, the samples were mixed with a $\gamma$ $\mathrm{Al}_{2} \mathrm{O}_{3}$ binder (inactive under the used conditions) in a weight ratio of $1: 1$, pelletized and fractionated. The tests were performed with the fraction 0.8-1.4 mm. Effect of mixing with $\mathrm{Al}_{2} \mathrm{O}_{3}$ was taken into account during the calculations of catalytic activity.

\section{TPR}

The temperature-programmed reduction in hydrogen (TPR- $\left.\mathrm{H}_{2}\right)$ was performed with $100 \mathrm{mg}$ of a sample in a quartz reactor using a flow setup equipped with a thermal conductivity detector. The reducing mixture $\left(10\right.$ vol\% of $\mathrm{H}_{2}$ in $\mathrm{Ar}$ ) was fed at $40 \mathrm{~mL} \mathrm{~min}^{-1}$. The rate of heating from room temperature to $900{ }^{\circ} \mathrm{C}$ was approximately $10^{\circ} \mathrm{C} \mathrm{min}^{-1}$.

\section{TG}

The experiments were made on a STA 409 PC Luxx (Netzsch) derivatograph. Concentrations of the gas mixture components were measured using a QMS-200 mass spectrometer. Samples were heated to $1000{ }^{\circ} \mathrm{C}$ at a rate of $10{ }^{\circ} \mathrm{C} \mathrm{min}{ }^{-1}$. Argon flow rate was $70 \mathrm{~mL} \min ^{-1}$.

\section{Results and discussion}

\section{State of the initial samples}

XRD and TG in argon. Phase composition of samples with $\mathrm{Mn}$ : Ga ratio $1.7: 1.3$ synthesized at $600-1200{ }^{\circ} \mathrm{C}$ in argon corresponds mainly to the $\mathrm{Mn}_{3-x} \mathrm{Ga}_{x} \mathrm{O}_{4}$ spinel phase [JCPDS no. 38-0181]. Lattice parameters and average CSR sizes are listed in Table 1 . One can see that CSR and lattice parameters of spinel increase with temperature. The origin of differences in the lattice parameters was discussed in details in our previous work ${ }^{\mathbf{1 7}}$ and is related to the presence of excess oxygen.

Table 1 lists weight losses of $\mathrm{Mn}_{1.7} \mathrm{Ga}_{1.3} \mathrm{O}_{4} \quad 600-1200{ }^{\circ} \mathrm{C}$ samples upon heating in an argon flow from 25 to $1000{ }^{\circ} \mathrm{C}$. As the calcination temperature is raised, weight losses decrease from $1.65 \%$ for the oxide synthesized at $600{ }^{\circ} \mathrm{C}$ to $0 \%$ for $1200{ }^{\circ} \mathrm{C}$. The oxygen content in spinel was estimated under the assumption that weight losses are related to the loss of excess oxygen in comparison with the stoichiometric ratio $\mathrm{M}: \mathrm{O}=$ $3: 4$, where $\mathrm{M}$ is $\mathrm{Ga}$ or $\mathrm{Mn}$. Such oxygen is weakly bound and can readily pass into the gas phase when the temperature is increased and/or the oxygen partial pressure is decreased. According to these data, the content of excess oxygen decreases with increasing the treatment temperature.

According to XRD date upon heating to $1000^{\circ} \mathrm{C}$ in argon, the spinel structure is retained, but the lattice parameter increases from $8.413(4)$ to $8.460(1) \AA$, which can be attributed to the observed oxygen losses. ${ }^{17}$

XPS. The surface state of the tested mixed oxides was characterized by XPS. The binding energy scale for the MnGa-600 sample was calibrated against the $\mathrm{C} 1 \mathrm{~s}$ peak of carbon $\left(E_{\mathrm{b}}=\right.$ $284.8 \mathrm{eV}$ ); therewith, the binding energy of the Ga $2 \mathrm{p}_{3 / 2}$ peak was $1117.9 \mathrm{eV}$. For all other samples, the binding energy scale was calibrated against the internal standard using the Ga $2 \mathrm{p}_{3 / 2}$ peak $\left(E_{\mathrm{b}}=1117.9 \mathrm{eV}\right)$.

Fig. 1 shows the Ga 2 p spectra of the tested samples. The Ga $2 \mathrm{p}$ spectrum is represented by the Ga $2 \mathrm{p}_{3 / 2}-\mathrm{Ga} 2 \mathrm{p}_{1 / 2}$ spin-orbital doublet, and the integral intensity ratio of its lines is $2: 1$. The Ga $2 p_{3 / 2}$ spectra of the tested samples are described by a single symmetric peak with the binding energy in the region of $1117.9 \mathrm{eV}$. According to the literature,${ }^{21-23}$ position of the peak corresponds to gallium in the $\mathrm{Ga}^{3+}$ state. The state of

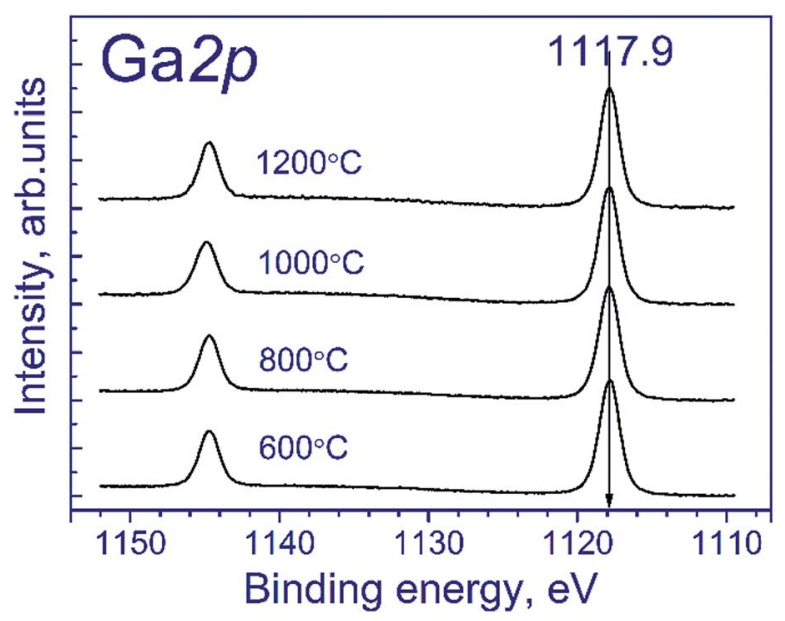

Fig. 1 Ga 2p spectra of the studied samples.

Table 1 Characteristics of the samples: lattice parameter, average CSR size, weight loss, and excess oxygen $\delta$ in $\mathrm{Mn}_{1.7} \mathrm{Ga}_{1.3} \mathrm{O}_{4+\delta}$ estimated by TG in argon

\begin{tabular}{lllll}
\hline $\begin{array}{l}\text { Calcination temperature } \\
\text { of oxide, }{ }^{\circ} \mathrm{C}\end{array}$ & $\begin{array}{l}\text { Lattice parameter } \\
\text { of } \mathrm{Mn}_{1.7} \mathrm{Ga}_{1.3} \mathrm{O}_{4}, \AA\end{array}$ & $\mathrm{CSR}, \AA$ & Weight loss, \% & $\begin{array}{l}\text { Estimated oxygen } \\
\text { excess } \delta \text { in } \mathrm{Mn}_{1.7} \mathrm{Ga}_{1.3} \mathrm{O}_{4+\delta}\end{array}$ \\
\hline 600 & $8.413(4)$ & 100 & 1.65 & 0.26 \\
800 & $8.462(1)$ & 350 & 0.5 & 0.08 \\
1000 & $8.481(1)$ & 650 & 0 & 0.00 \\
1200 & $8.478(1)$ & $>1000$ & 0 & 0.00
\end{tabular}


manganese is commonly identified using the $\mathrm{Mn} 2 \mathrm{p}_{3 / 2}$ binding energy: according to the literature, ${ }^{24-37}$ manganese in $\mathrm{MnO}$, $\mathrm{Mn}_{2} \mathrm{O}_{3}$ and $\mathrm{MnO}_{2}$ oxides is characterized by the $\mathrm{Mn} 2 \mathrm{p}_{3 / 2}$ binding energy in the range of 640.4-641.7, 641.5-641.9, and 642.2-642.6 eV, respectively. As seen from the indicated data, $\mathrm{Mn}^{2+}$ and $\mathrm{Mn}^{3+}$ compounds have close binding energies of $\mathrm{Mn}$ $2 \mathrm{p}_{3 / 2}$, which complicate their identification.

To identify correctly the manganese state, it is necessary to take into account also the shape of Mn 2p spectrum, specifically, the intensity and relative position of shake-up satellites, the presence of which is determined by multielectron processes. ${ }^{26,28,38}$ To estimate parameters of the Mn 2p spectra deconvolution into individual components, we recorded the spectra of reference compounds $\mathrm{Mn}_{3} \mathrm{O}_{4}, \mathrm{Mn}_{2} \mathrm{O}_{3}$, and $\mathrm{MnO}_{2}$, which contain manganese in the $\mathrm{Mn}^{2+}, \mathrm{Mn}^{3+}$ and $\mathrm{Mn}^{4+}$ states, respectively.

Fig. 2a shows the Mn 2p spectra of manganese oxides. It is known that the Mn $2 \mathrm{p}$ spectrum is represented by the $\mathrm{Mn} 2 \mathrm{p}_{3 / 2}$ Mn $2 \mathrm{p}_{1 / 2}$ spin-orbital doublet whose integral intensity ratio is $2: 1$ and spin-orbital splitting (the difference between binding energies of $\mathrm{Mn} 2 \mathrm{p}_{1 / 2}$ and $\mathrm{Mn} 2 \mathrm{p}_{3 / 2}$ ) is $11.8 \mathrm{eV}$. The Mn 2p spectrum of $\mathrm{Mn}_{2} \mathrm{O}_{3}$ comprises the $\mathrm{Mn} 2 \mathrm{p}_{3 / 2}-\mathrm{Mn} 2 \mathrm{p}_{1 / 2}$ doublet and the corresponding shake-up satellites; the binding energy of $\mathrm{Mn} 2 \mathrm{p}_{3 / 2}$ is $641.5 \mathrm{eV}$, and the difference in binding energy between the Mn $2 \mathrm{p}_{3 / 2}$ peak and the corresponding shake-up satellite is $10.1 \mathrm{eV}$. A similar pattern is observed for $\mathrm{MnO}_{2}$, the binding energy being equal to $642.2 \mathrm{eV}$, and the difference in binding energy between the $\mathrm{Mn} 2 \mathrm{p}_{3 / 2}$ peak and its shake-up satellite, $11.4 \mathrm{eV}$.

The $\mathrm{Mn}_{3} \mathrm{O}_{4}$ compound comprises both the $\mathrm{Mn}^{2+}$ and $\mathrm{Mn}^{3+}$ cations; therewith, the fraction of $\mathrm{Mn}^{2+}$ constitutes $33 \%$, and that of $\mathrm{Mn}^{3+}, 67 \%$. The fitting of the Mn 2p spectrum revealed that in the synthesized $\mathrm{Mn}_{3} \mathrm{O}_{4}$ compound the fraction of $\mathrm{Mn}^{2+}$ constitutes $40 \%$, and $\mathrm{Mn}^{3+}, 60 \%$, which is close to the stoichiometric composition. The Mn $2 \mathrm{p}_{3 / 2}$ binding energy of the $\mathrm{Mn}^{2+}$ state is $640.8 \mathrm{eV}$, and the difference in binding energy between the Mn 2 $\mathrm{p}_{3 / 2}$ peak and the corresponding shake-up satellite, $6.4 \mathrm{eV}$. As was noted above, fitting parameters
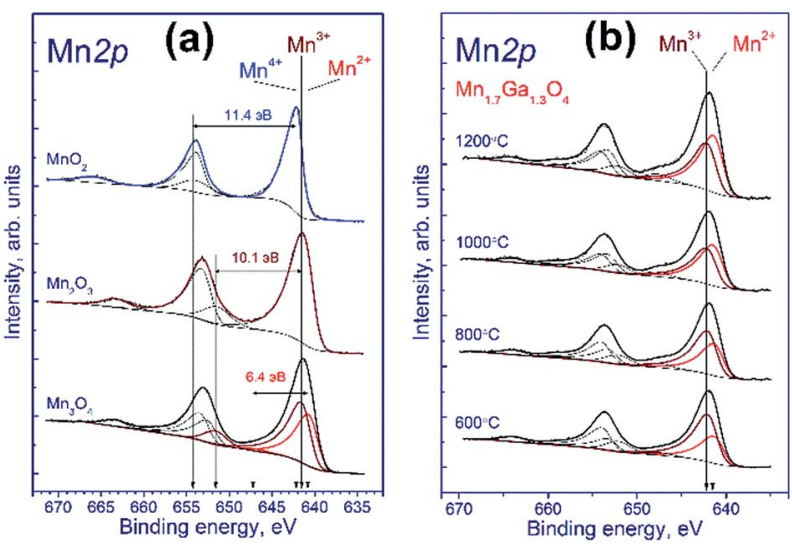

Fig. $2 \mathrm{Mn} 2 \mathrm{p}$ spectra of the studied samples. The spectra were normalized to the integral intensity of the corresponding Ga $2 p$ spectra. obtained for the model manganese compounds were used to identify the states of manganese in the tested Mn-Ga systems.

Fig. $2 \mathrm{~b}$ shows the Mn 2p spectra of mixed Mn-Ga oxides treated in argon at different temperatures. The Mn 2p spectra are described by two $\mathrm{Mn} 2 \mathrm{p}_{3 / 2}-\mathrm{Mn} 2 \mathrm{p}_{1 / 2}$ doublets assigned to manganese in the $\mathrm{Mn}^{2+}$ and $\mathrm{Mn}^{3+}$ states, and by the corresponding shake-up satellites located at a distance of 6.4 and $10.1 \mathrm{eV}$ from the main peaks. It should be noted that the Mn $2 \mathrm{p}$ spectra of the tested samples have no peaks located at a distance of $11.4 \mathrm{eV}$ from the main peak, which is typical of the shake-up satellite of manganese in the $\mathrm{Mn}^{4+}$ state. In other words, manganese in the systems under consideration is in two states, $\mathrm{Mn}^{2+}$ and $\mathrm{Mn}^{3+}$. The $\mathrm{Mn} 2 \mathrm{p}_{3 / 2}$ peak assigned to manganese in the $\mathrm{Mn}^{2+}$ state lays at $641.5-641.6 \mathrm{eV}$, and that of manganese in the $\mathrm{Mn}^{3+}$ state, at $642.2-642.3 \mathrm{eV}$. Therewith, the indicated binding energies are higher than those observed for model manganese compounds $\mathrm{Mn}_{3} \mathrm{O}_{4}$ and $\mathrm{Mn}_{2} \mathrm{O}_{3}(640.8 \mathrm{eV}$ for $\mathrm{Mn}^{2+}$ and $641.5 \mathrm{eV}$ for $\mathrm{Mn}^{3+}$ ). A likely cause of the revealed differences is that manganese resides in the structure of mixed oxide whose local environment differs from the environment in simple oxide, and this produces the observed increase in the Mn $2 \mathrm{p}_{3 / 2}$ binding energy.

The relative concentrations (atomic ratios) of elements in the subsurface layer of the samples estimated by XPS and the Mn $2 \mathrm{p}_{3 / 2}$ binding energies are listed in Table 2 . For the samples synthesized at $600-1000{ }^{\circ} \mathrm{C}$, the $[\mathrm{Mn}] /[\mathrm{Ga}]$ atomic ratio was 1.36-1.39, which is close to the stoichiometric composition 1.31 , whereas for the sample treated at $1200{ }^{\circ} \mathrm{C}$, a much higher atomic ratio, 1.87, was observed. Hence, an increase in the calcination temperature is accompanied by surface enrichment with manganese cations. For the low-temperature oxides treated at $600-800{ }^{\circ} \mathrm{C}, 67-60 \%$ of manganese cations in the $3+$ state are observed, while for the high-temperature oxides this value is somewhat lower, $\sim 50 \%$. For a compound with the composition $\mathrm{Mn}_{1.7} \mathrm{Ga}_{1.3} \mathrm{O}_{4}$, according to electroneutrality balance, $\mathrm{Mn}^{3+}$ should constitute $41 \%$, and $\mathrm{Mn}^{2+} 59 \%$; however, all the tested samples have a greater $\mathrm{Mn}^{3+}$ amount. Such behavior can be attributed to the oxidation on the manganese surface; but the presence of excess oxygen in the low-temperature oxides, as revealed by TG and XRD, should be taken into account as well.

Catalytic activity in CO oxidation. Fig. 3a shows the catalytic activity of $\mathrm{Mn}-\mathrm{Ga}$ oxides per gram of catalyst and per unit surface area in the oxidation of $\mathrm{CO}$ as a function of calcination temperature. One can see that the catalytic activity per gram

Table 2 Atomic ratios of elements in subsurface layer of samples. The $\mathrm{Mn} 2 \mathrm{p}_{3 / 2}$ binding energies. The binding energy scale was calibrated using the $\mathrm{Ga} 2 \mathrm{p}_{3 / 2}$ peak at $1117.9 \mathrm{eV}$

\begin{tabular}{|c|c|c|c|c|c|c|c|}
\hline \multirow[b]{2}{*}{ Sample } & \multicolumn{3}{|c|}{$[\mathrm{Mn}] /[\mathrm{Ga}]$} & \multicolumn{4}{|c|}{ Mn $2 p_{3 / 2}$} \\
\hline & Total & {$\left[\mathrm{Mn}^{2+}\right] /[\mathrm{Ga}]$} & {$\left[\mathrm{Mn}^{3+}\right] /[\mathrm{Ga}]$} & $\mathrm{Mn}^{2+}$ & $\mathrm{Mn}^{3+}$ & $2+, \%$ & $3+, \%$ \\
\hline $600{ }^{\circ} \mathrm{C}$ & 1.37 & 0.45 & 0.91 & 641.6 & 642.2 & 33 & 67 \\
\hline $800{ }^{\circ} \mathrm{C}$ & 1.36 & 0.55 & 0.82 & 641.5 & 642.2 & 40 & 60 \\
\hline $1000^{\circ} \mathrm{C}$ & 1.39 & 0.69 & 0.70 & 641.6 & 642.3 & 50 & 50 \\
\hline $1200^{\circ} \mathrm{C}$ & 1.87 & 0.97 & 0.91 & 641.5 & 642.3 & 52 & 48 \\
\hline
\end{tabular}




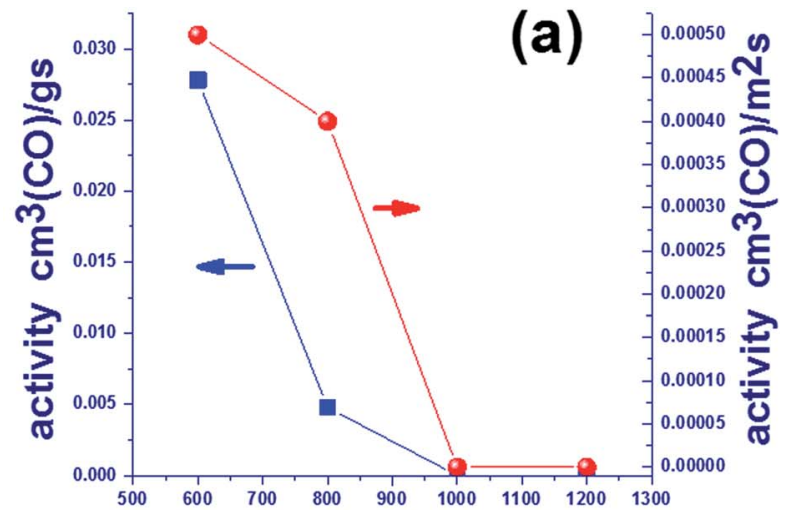

Calcination temperature, ${ }^{\circ} \mathrm{C}$

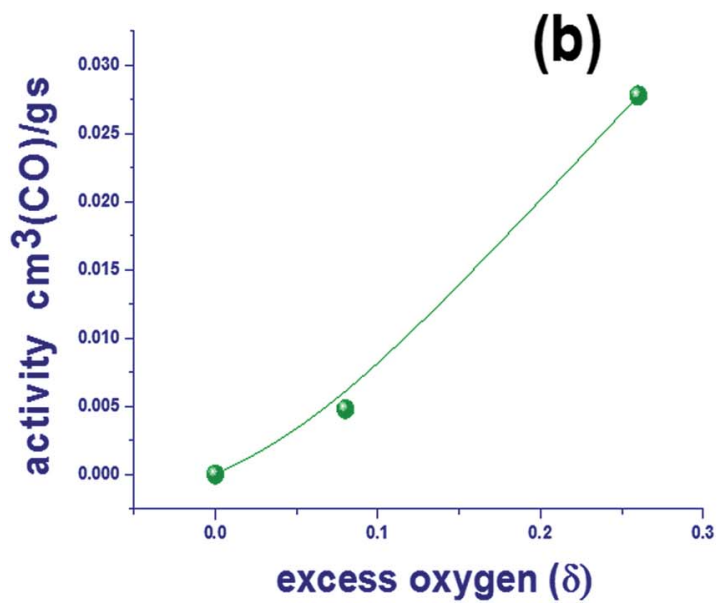

Fig. 3 The catalytic activity of Mn-Ga oxides per gram of catalyst and per unit surface area in the oxidation of $\mathrm{CO}$ at $275^{\circ} \mathrm{C}$ for oxides prepared at different temperatures (a), and the dependence of catalytic activity of the $\mathrm{Mn}-\mathrm{Ga}$ oxides per gram of catalyst and quantity of excess oxygen according to TG data (b).

decreases to zero with increasing the temperature of oxide synthesis. The activity in the oxidation of CO referred to unit surface area also decreases when the calcination temperature is increased. It should be noted that non-zero activity in the oxidation of $\mathrm{CO}$ is observed for the samples containing excess oxygen. The content of excess oxygen correlates with the ratio of $\mathrm{Mn}^{2+} / \mathrm{Mn}^{3+}$ on the surface (Table 2). In addition, there is a correlation between the catalytic activity and the amount of excess oxygen $\delta$ in $\mathrm{Mn}_{1.7} \mathrm{Ga}_{1.3} \mathrm{O}_{4+\delta}$ derived from TG data (Fig. 3b). Thus, characterization of the synthesized samples by XRD, TG, and XPS showed that the low-temperature (600-800 ${ }^{\circ} \mathrm{C}$ ) oxides differ from the high-temperature $\left(1000-1200{ }^{\circ} \mathrm{C}\right)$ ones by the presence of excess - nonstoichiometric oxygen, which is active in the catalytic oxidation of CO.

Since the spinel structure has the closest oxygen packing, the presence of additional oxygen should indicate the occurrence of defects - cationic vacancies. This suggests that an increase in the synthesis temperature results in a loss of excess oxygen, which decreases the number of cationic vacancies. Oxygen losses may be related not only to the oxidized surface (according to XPS) but also to the bulk structure, because an increase in the lattice parameters is observed (Table 1). Further studies are focused on the reduction of $\mathrm{Mn}-\mathrm{Ga}$ and are aimed to reveal changes in the bulk and on the surface of the system during a loss of excess oxygen.

\section{Investigation of the hydrogen reduction of $\mathrm{Mn}_{1.7} \mathrm{Ga}_{1.3} \mathrm{O}_{4}$ spinel}

TPR-H2. Fig. 4 shows TPR curves for the series of samples under consideration; for comparison purposes, the corresponding data for $\mathrm{Mn}_{2} \mathrm{O}_{3}$ and $\mathrm{Mn}_{3} \mathrm{O}_{4}$ are also shown. One can see that the reduction of $\mathrm{Mn}_{3} \mathrm{O}_{4}$ is characterized by one hydrogen absorption peak with the maximum at $510{ }^{\circ} \mathrm{C}\left(\mathrm{Mn}_{3} \mathrm{O}_{4}\right.$ $\rightarrow \mathrm{MnO}$ ), whereas $\mathrm{Mn}_{2} \mathrm{O}_{3}$ is characterized by two peaks at 390 and $410{ }^{\circ} \mathrm{C}$, corresponding to the two-step reduction $\mathrm{Mn}_{2} \mathrm{O}_{3} \rightarrow$ $\mathrm{Mn}_{3} \mathrm{O}_{4} \rightarrow \mathrm{MnO} .^{39,40}$

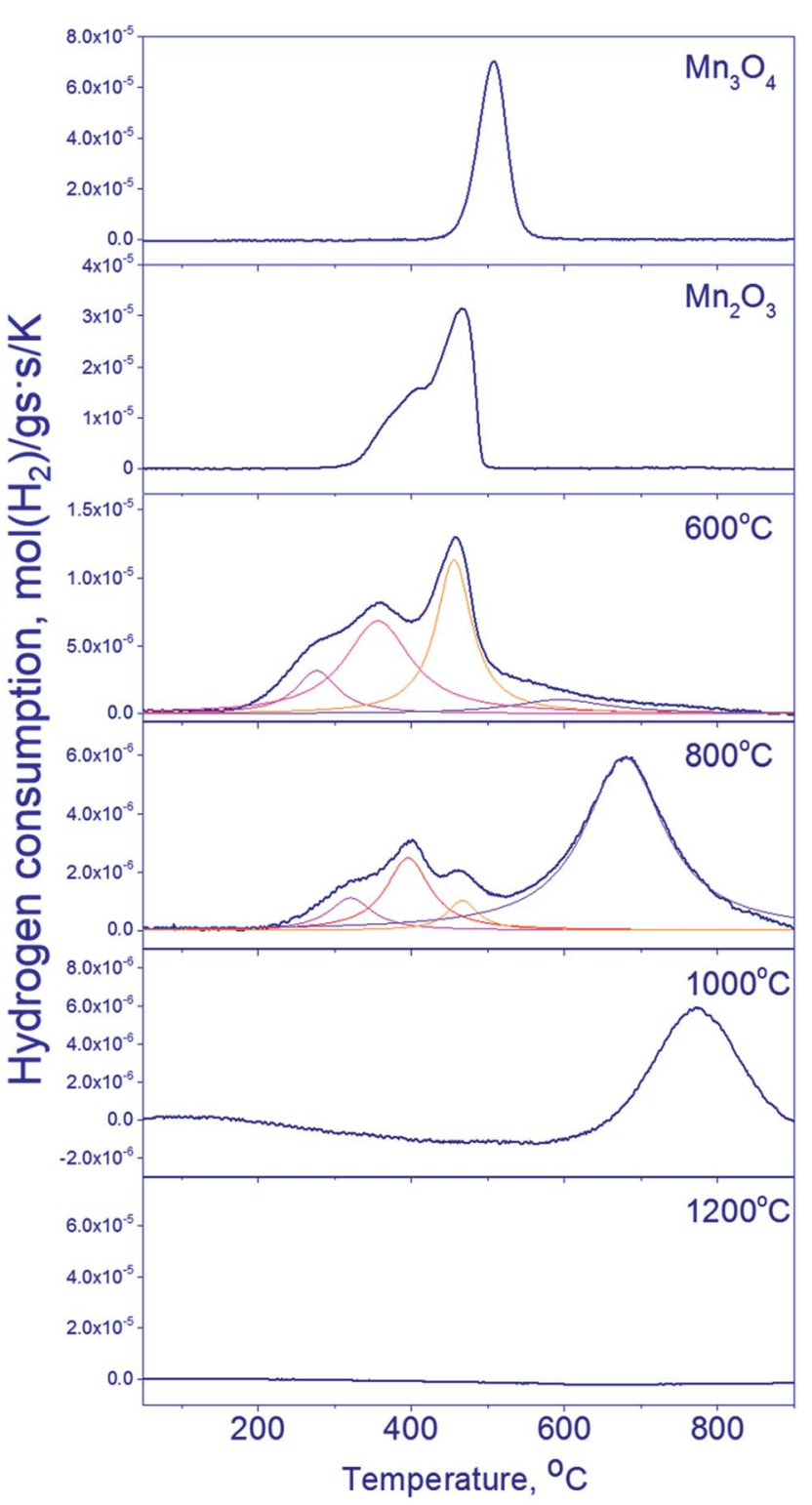

Fig. 4 TPR profiles of $\mathrm{Mn}_{1.7} \mathrm{Ga}_{1.3} \mathrm{O}_{4} 600-1200{ }^{\circ} \mathrm{C}$ and simple oxides $\left(\mathrm{Mn}_{2} \mathrm{O}_{3}\right.$ and $\left.\mathrm{Mn}_{3} \mathrm{O}_{4}\right)$. 
The reduction of mixed $\mathrm{Mn}-\mathrm{Ga}$ oxides differs essentially from the reduction of simple oxides. Low-temperature peaks at 280-470 ${ }^{\circ} \mathrm{C}$ and high-temperature peaks at $600-770{ }^{\circ} \mathrm{C}$ are observed on the TPR curves. Hydrogen absorption in two temperature ranges is typical of the samples synthesized at 600$800{ }^{\circ} \mathrm{C}$. Therewith, the $\mathrm{Mn}_{1.7} \mathrm{Ga}_{1.3} \mathrm{O}_{4}-800{ }^{\circ} \mathrm{C}$ sample has a pronounced hydrogen absorption peak at $680{ }^{\circ} \mathrm{C}$; absorption in the region of $500-700{ }^{\circ} \mathrm{C}$ without a distinct maximum is observed on the curve of $\mathrm{Mn}_{1.7} \mathrm{Ga}_{1.3} \mathrm{O}_{4}-600{ }^{\circ} \mathrm{C}$. The TPR profile of the oxide treated at $1000{ }^{\circ} \mathrm{C}$ has only the high-temperature peak at $770{ }^{\circ} \mathrm{C}$. Hydrogen absorption is not observed in $\mathrm{Mn}_{1.7} \mathrm{Ga}_{1.3} \mathrm{O}_{4}-1200{ }^{\circ} \mathrm{C}$; probably, it is reduced at higher temperatures $\left(>900{ }^{\circ} \mathrm{C}\right)$.

For $\mathrm{Mn}_{1.7} \mathrm{Ga}_{1.3} \mathrm{O}_{4}$ compounds calcined at 600 and $800{ }^{\circ} \mathrm{C}$, it can be supposed that TPR maxima in the low-temperature region correspond to the removal of weakly bound oxygen. Similar low-temperature TPR peaks were observed upon reduction of $\mathrm{MnFe}_{2} \mathrm{O}_{4}$, which was synthesized by the sol-gel method with subsequent calcination at $400-600{ }^{\circ} \mathrm{C}$ in air. The TPR curve had three peaks, which were assigned to the following reduction sequence: $\mathrm{MnFe}_{2} \mathrm{O}_{4} \rightarrow \mathrm{MnFe}_{2} \mathrm{O}_{4-\delta} \rightarrow$ MnO-FeO-solid solution $\rightarrow \alpha-\mathrm{Fe}^{41}$

The higher is the calcination temperature, the stronger is the shift of hydrogen absorption peaks toward high temperatures, which produces a decrease in the total amount of absorbed hydrogen (Table 3).

The high-temperature TPR maximum at $600-800{ }^{\circ} \mathrm{C}$ obviously corresponds to the reduction of manganese cations to the $\mathrm{Mn}^{2+}$ state. Whether the reduction proceeds in the bulk of spinel or is accompanied by the release of $\mathrm{MnO}$ as a single phase - this question will be elucidated by means of in situ XRD and XPS.

In situ XRD. To reveal structural transformations accompanying the reduction of $\mathrm{Mn}-\mathrm{Ga}$ mixed oxides, in situ XRD experiments were performed with heating of the sample synthesized at $600{ }^{\circ} \mathrm{C}$ in hydrogen (Fig. 5). As the temperature is raised, spinel peaks are shifted toward smaller angles; at 500$550{ }^{\circ} \mathrm{C}$ a shoulder appears near the spinel reflection in the region of $2 \theta=41^{\circ}$; and at a further increase in temperature, this shoulder transforms into the peak at $2 \theta=40.5^{\circ}$ corresponding to the 200 reflection of MnO. During the reduction, spinel particles increased in size from 85 to $120 \AA$.

Table 3 TPR data for $\mathrm{Mn}_{1.7} \mathrm{Ga}_{1.3} \mathrm{O}_{4} 600-1200{ }^{\circ} \mathrm{C}$

\begin{tabular}{llll}
\hline Sample & $T_{\max }$ & $\begin{array}{l}\text { Amount of absorbed } \\
\text { hydrogen, mmol g }\end{array}$ & $\begin{array}{l}\text { Total hydrogen } \\
\text { absorption, mmol g }\end{array}$ \\
\hline $600{ }^{\circ} \mathrm{C}$ & 280 & 0.33 & 3.45 \\
& 355 & 1.09 & \\
& 455 & 1.04 & \\
$800{ }^{\circ} \mathrm{C}$ & 320 & 0.15 & 2.07 \\
& 400 & 0.29 & \\
& 470 & 0.09 & \\
$1000{ }^{\circ} \mathrm{C}$ & 680 & 1.57 & 0.93
\end{tabular}

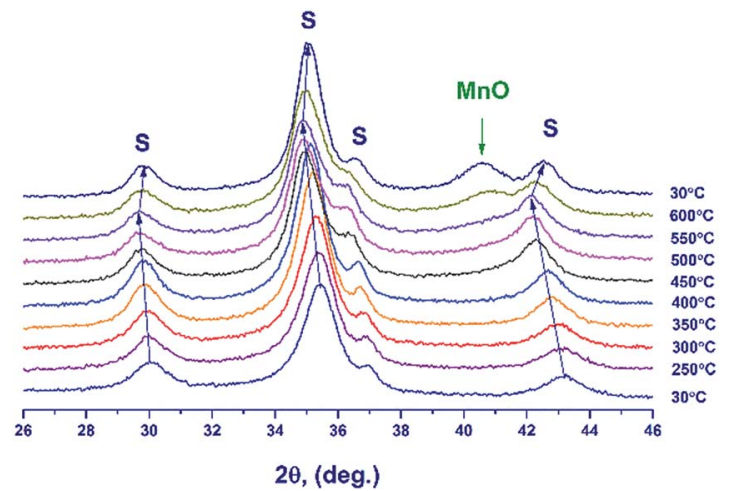

Fig. 5 In situ XRD patterns recorded during the hydrogen reduction of $\mathrm{Mn}-\mathrm{Ga}$ oxide synthesized at $600{ }^{\circ} \mathrm{C}$ in the temperature range from 30 to $600{ }^{\circ} \mathrm{C}$. Reflections from $\mathrm{Mn}_{1.7} \mathrm{Ga}_{1.3} \mathrm{O}_{4}$ spinel are denoted by symbol S

Fig. 6 illustrates the temperature dependence of the spinel lattice parameters upon reduction. The lattice parameter increases from 8.413 to $8.560 \AA$ in the range from 30 to $450{ }^{\circ} \mathrm{C}$ and then drops to $8.501 \AA$. The decrease in the lattice parameter is accompanied by the formation of the MnO phase.

For comparison purposes, Fig. 6 shows also the $[\mathrm{Mn}] /[\mathrm{Ga}]$ atomic ratio on the surface as revealed by XPS, which will be discussed below.

An additional experiment was carried out to exclude the effect of thermal expansion: after heating in a hydrogen flow to $450{ }^{\circ} \mathrm{C}$ (until the $\mathrm{MnO}$ phase is formed) and to $600^{\circ} \mathrm{C}$, the lattice parameter was measured at room temperature.

In the temperature range of $25-450{ }^{\circ} \mathrm{C}$, the unit cell parameter of spinel increases from 8.413(4) to 8.492(2) $\AA$. The observed increase in the lattice parameter cannot be related to segregation of Mn cations on the surface (the XPS data are presented below) because an increase in the relative content of $\mathrm{Ga}^{3+}$ in the spinel bulk should decrease the lattice parameter. Thus, the observed change in the lattice parameter correlates

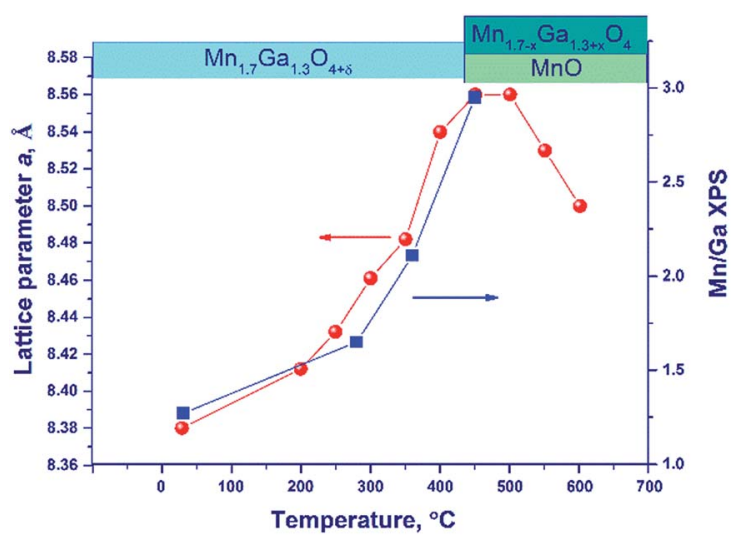

Fig. 6 The lattice parameter of spinel (circles) and the [Mn]/[Ga] atomic ratio on the oxide surface (squares) versus temperature upon hydrogen reduction of the $\mathrm{Mn}-\mathrm{Ga}$ oxide synthesized at $600{ }^{\circ} \mathrm{C}$. The dynamics of phase transformations is illustrated by the diagram in the upper part of the figure. 
with the loss of excess oxygen (the low-temperature TPR peak, Fig. 4). Nevertheless, noteworthy is the fact that the lattice parameter of spinel at $450{ }^{\circ} \mathrm{C}(8.492(2) \AA)$ exceeds the parameters of the high-temperature oxides under consideration, 8.481(1)-8.478(1) $\AA$ (1000 and $1200{ }^{\circ} \mathrm{C}$ ), although the indicated samples do not contain excess oxygen (according to the TG and TPR data). This may be related to rearrangements in the spinel structure and charge state of manganese cations.

At $600{ }^{\circ} \mathrm{C}$ the lattice parameter decreases to $8.454 \AA$, which is accompanied by the emergence of the MnO phase. The spinel parameter after reduction at $600{ }^{\circ} \mathrm{C}$ is close to the value indicated for $\mathrm{Mn}_{1} \mathrm{Ga}_{2} \mathrm{O}_{4}, 8.451 \AA$ [JCPDS no. 38-0181]. A decrease in the lattice parameter during the reduction at $500-600{ }^{\circ} \mathrm{C}$ is associated with the release of manganese cations from the solid solution to the $\mathrm{MnO}$ phase and with the increase in the relative Ga content in spinel. Accordingly, it can be expected that at $600{ }^{\circ} \mathrm{C}$ manganese cations are completely reduced to $\mathrm{Mn}^{2+}$ with the formation of $\mathrm{MnGa}_{2} \mathrm{O}_{4}$ and $\mathrm{MnO}$ phases.

Thus, the reduction is accompanied by changes in the lattice parameter, which testify to structural rearrangements caused by the removal of excess oxygen and the release of manganese cations with the formation of $\mathrm{MnO}$ oxide.

Pseudo in situ XPS analysis. To compare the behavior on the surface and in the bulk of the particle upon reduction, pseudo in situ XPS measurements were performed. Two experiments were carried out with the low-temperature sample: (1) treatment with argon at 200 and $400{ }^{\circ} \mathrm{C}$, and (2) hydrogen reduction at the temperatures corresponding to the TPR maxima at 280, 360, and $450{ }^{\circ} \mathrm{C}$. Table 4 lists the atomic ratios of elements in subsurface layer of the tested samples of mixed Mn-Ga oxide. Table 5 shows the $\mathrm{Mn} 2 \mathrm{p}_{3 / 2}$, Ga $2 \mathrm{p}_{3 / 2}$, and $\mathrm{O} 1 \mathrm{~s}$ binding energies as well as the content of $\mathrm{Mn}^{2+}$ and $\mathrm{Mn}^{3+}$ cations.

As for the initial samples, the Ga $2 \mathrm{p}$ spectra of $\mathrm{Mn}-\mathrm{Ga}$ oxide $\left(600{ }^{\circ} \mathrm{C}\right)$ recorded after treatment in argon and reduction in hydrogen are described by one symmetric peak at $1117.9 \mathrm{eV}$ (spectra not shown), which corresponds to $\mathrm{Ga}^{3+} \cdot{ }^{19-21}$ This peak was used for calibration of the binding energy scale.

Fig. 7a shows the Mn 2p spectra of the tested sample that were recorded after the treatment in argon. According to

Table 4 Atomic ratios of elements in the subsurface layer of $\mathrm{Mn}-\mathrm{Ga}$ oxide synthesized at $600{ }^{\circ} \mathrm{C}$ under different treatment conditions ${ }^{a}$

\begin{tabular}{|c|c|c|c|c|c|c|}
\hline \multirow{2}{*}{$\begin{array}{l}\text { Treatment } \\
\text { (temperature } \\
\text { and medium) }\end{array}$} & \multicolumn{3}{|c|}{$[\mathrm{Mn}] /[\mathrm{Ga}]$} & \multirow[b]{2}{*}{$\begin{array}{l}{\left[\mathrm{O}^{*}\right] /} \\
{[\mathrm{Mn}]}\end{array}$} & \multirow[b]{2}{*}{$\begin{array}{l}{\left[\mathrm{O}^{*}\right] /} \\
{[\mathrm{Ga}]}\end{array}$} & \multirow[b]{2}{*}{$\begin{array}{l}{\left[\mathrm{O}^{*}\right] /} \\
{[\mathrm{Mn}]+[\mathrm{Ga}]}\end{array}$} \\
\hline & Total & $\begin{array}{l}{\left[\mathrm{Mn}^{2+}\right] /} \\
{[\mathrm{Ga}]}\end{array}$ & $\begin{array}{l}{\left[\mathrm{Mn}^{3+}\right] /} \\
{[\mathrm{Ga}]}\end{array}$ & & & \\
\hline \multicolumn{7}{|c|}{ Treatment in Ar } \\
\hline Fresh & 1.37 & 0.45 & 0.91 & 2.45 & 3.35 & 1.4 \\
\hline $200{ }^{\circ} \mathrm{C}-\mathrm{Ar}$ & 1.48 & 0.73 & 0.75 & 2.3 & 3.4 & 1.4 \\
\hline $400{ }^{\circ} \mathrm{C}-\mathrm{Ar}$ & 1.54 & 0.96 & 0.58 & 1.9 & 2.9 & 1.2 \\
\hline
\end{tabular}

Treatment in $\mathbf{H}_{2}$

$\begin{array}{lllllll}280^{\circ} \mathrm{C}-\mathrm{H}_{2} & 1.81 & 1.04 & 0.77 & 2.31 & 4.17 & 1.5 \\ 360{ }^{\circ} \mathrm{C}-\mathrm{H}_{2} & 2.33 & 1.00 & 1.33 & 1.39 & 3.23 & 0.97 \\ 450{ }^{\circ} \mathrm{C}-\mathrm{H}_{2} & 3.26 & 1.22 & 2.04 & 1.24 & 4.03 & 0.95\end{array}$

${ }^{a}\left[\mathrm{O}^{*}\right]$ - oxygen in the structure of mixed oxide.
Table $5 \mathrm{Mn} 2 \mathrm{p}_{3 / 2}$ and $\mathrm{Ga} 2 \mathrm{p}_{3 / 2}$ binding energies (eV). The binding energy scale was calibrated against the $\mathrm{Ga} 2 \mathrm{p}_{3 / 2}$ peak at $1117.9 \mathrm{eV}$

\begin{tabular}{|c|c|c|c|c|c|c|}
\hline \multirow{2}{*}{$\begin{array}{l}\text { Treatment } \\
\text { (temperature } \\
\text { and medium) }\end{array}$} & \multicolumn{4}{|c|}{$\mathrm{Mn} 2 \mathrm{p}_{3 / 2}$} & \multirow[b]{2}{*}{$\mathrm{Ga} 2 \mathrm{p}_{3 / 2}$} & \multirow[b]{2}{*}{ O 1s } \\
\hline & $\mathrm{Mn}^{2+}$ & $\mathrm{Mn}^{3+}$ & $\mathrm{Mn}^{2+}, \%$ & $\mathrm{Mn}^{3+}, \%$ & & \\
\hline \multicolumn{7}{|c|}{ Treatment in Ar } \\
\hline Fresh & 641.6 & 642.2 & 33 & 67 & 1117.9 & 530.6 \\
\hline $200{ }^{\circ} \mathrm{C}-\mathrm{Ar}$ & 641.0 & 642.2 & 49 & 51 & 1117.9 & 530.6 \\
\hline $400{ }^{\circ} \mathrm{C}-\mathrm{Ar}$ & 640.9 & 642.3 & 62 & 38 & 1117.9 & 530.6 \\
\hline \multicolumn{7}{|c|}{ Treatment in $\mathbf{H}_{2}$} \\
\hline $280{ }^{\circ} \mathrm{C}-\mathrm{H}_{2}$ & 641.1 & 642.2 & 58 & 42 & 1117.9 & 530.6 \\
\hline $360{ }^{\circ} \mathrm{C}-\mathrm{H}_{2}$ & 641.1 & 641.8 & 43 & 57 & 1117.9 & 530.6 \\
\hline $450{ }^{\circ} \mathrm{C}-\mathrm{H}_{2}$ & 641.1 & 641.8 & 37 & 63 & 1117.9 & 530.3 \\
\hline
\end{tabular}
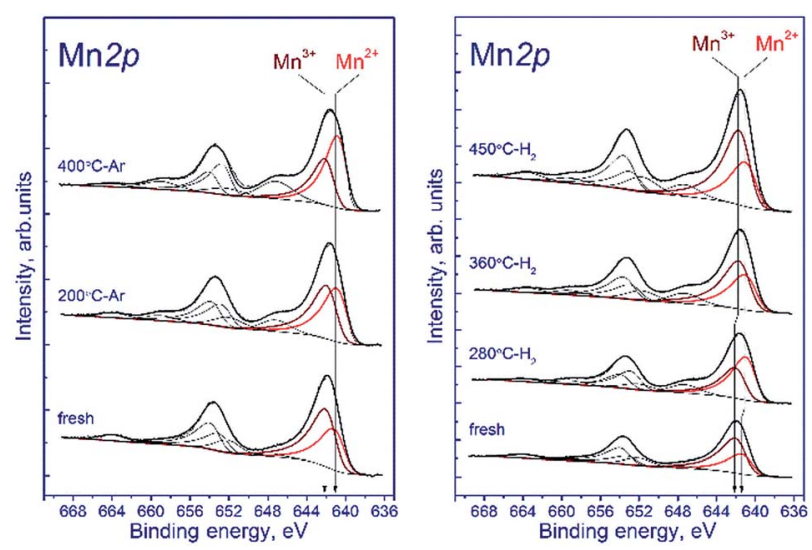

Fig. $7 \mathrm{Mn} 2 \mathrm{p}$ spectra of the studied samples. The spectra were normalized to the integral intensity of the corresponding Ga $2 p$ spectra.

deconvolution of the Mn 2p spectra of the sample into individual components, manganese is in two states, $\mathrm{Mn}^{2+}$ and $\mathrm{Mn}^{3+}$. As the treatment temperature is raised, the $M n 2 p_{3 / 2}$ peak attributed to manganese in the $\mathrm{Mn}^{2+}$ state shifts from 641.5 to $640.9 \mathrm{eV}$. A possible reason is the formation of the manganesecontaining particles on the sample surface in which the chemical environment of manganese is close to that in MnO. The Mn $2 \mathrm{p}_{3 / 2}$ peak assigned to manganese in the $\mathrm{Mn}^{3+}$ state lays at $642.2-642.3 \mathrm{eV}$ indicating that $\mathrm{Mn}^{3+}$ cations reside in the structure of a mixed Mn-Ga oxide.

Relative concentrations (atomic ratios) of elements in the subsurface layer, which were estimated by XPS, are listed in Table 5. The treatment in argon decreases the oxygen content: the $[\mathrm{O}] /[\mathrm{Mn}]$ atomic ratio droppes from 2.45 to 1.9. Simultaneously, the $[\mathrm{Mn}] /[\mathrm{Ga}]$ atomic ratio increases from 1.3 to 1.5 , which indicates that manganese is segregated as MnO on the surface of mixed oxide. This is evidenced also by an increase in the fraction of $\mathrm{Mn}^{2+}$ from $33 \%$ to $62 \%$. On the surface, the $\left[\mathrm{Mn}^{2+}\right] /[\mathrm{Ga}]$ ratio increases from 0.48 to 0.96 , while $\left[\mathrm{Mn}^{3+}\right] /[\mathrm{Ga}]$ decreases from 0.91 to 0.58 (Table 4). Surface enrichment with manganese is also observed for the initial sample calcined at $1200{ }^{\circ} \mathrm{C}$, in comparison with other samples of this series 
(Table 2). The $[\mathrm{O}] /[\mathrm{Mn}+\mathrm{Ga}]$ ratio decreases from 1.4 to 1.2, which agrees with the weight losses and the removal of excess oxygen revealed by TGA.

Fig. 7b shows the Mn 2p spectra of the tested sample that were recorded after its reduction in hydrogen. The shape of the Mn 2p spectra indicates that manganese is in two states, $\mathrm{Mn}^{2+}$ and $\mathrm{Mn}^{3+}$. The presence of manganese in the $\mathrm{Mn}^{4+}$ state is not observed. Similar to the treatment in argon, the treatment in hydrogen at $280{ }^{\circ} \mathrm{C}$ leads to the shift of the $\mathrm{Mn} 2 \mathrm{p}_{3 / 2}$ peak attributed to $\mathrm{Mn}^{2+}$ from 641.6 to $641.0 \mathrm{eV}$; this fact testifies to the formation of the manganese-containing particles on the catalyst surface in which the chemical environment of manganese is close to that in MnO. The Mn 2 $\mathrm{p}_{3 / 2}$ peak assigned to $\mathrm{Mn}^{3+}$ also shifts from 642.3 to $641.8 \mathrm{eV}$; however, the observed effect takes place at $360{ }^{\circ} \mathrm{C}$, which may indicate the formation of individual particles containing manganese in the $\mathrm{Mn}^{3+}$ state (probably $\mathrm{Mn}_{2} \mathrm{O}_{3}$ ). In both cases, the decrease in the Mn 2 $\mathrm{p}_{3 / 2}$ binding energy is accompanied by an abrupt increase in the $\left[\mathrm{Mn}^{2+}\right] /[\mathrm{Ga}]$ and $\left[\mathrm{Mn}^{3+}\right] /[\mathrm{Ga}]$ atomic ratios.

The surface content of $\mathrm{Mn}^{2+}$ increases from $33 \%$ to $58 \%$ upon reduction in hydrogen at $280{ }^{\circ} \mathrm{C}$ and then decreases to $43 \%\left(360^{\circ} \mathrm{C}\right)$ and $37 \%\left(450{ }^{\circ} \mathrm{C}\right)$ when the temperature is raised. The decrease in the relative content of $\mathrm{Mn}^{2+}$ on the surface during the hydrogen reduction seems unusual, because the process occurs in a reducing atmosphere and should be accompanied by a decrease in the oxidation state of manganese cations, as in the case of treatment in argon. However, the reduction is accompanied by segregation of manganese cations on the surface; therewith, the $\left[\mathrm{Mn}^{2+}\right] /[\mathrm{Ga}]$ atomic ratio gradually increases from 0.45 to 1.22 upon heating in hydrogen from 25 to $450{ }^{\circ} \mathrm{C}$. The $\left[\mathrm{Mn}^{3+}\right] /[\mathrm{Ga}]$ atomic ratio changes abruptly during the reduction: it decreases from 0.92 to 0.77 upon heating from 25 to $280{ }^{\circ} \mathrm{C}$, then sharply increases to 1.3 at $360{ }^{\circ} \mathrm{C}$, and reaches 2.0 at $450{ }^{\circ} \mathrm{C}$.

Upon reduction of the sample in hydrogen at different temperatures, the $[\mathrm{Mn}] /[\mathrm{Ga}]$ atomic ratios increase from 1.4 to 3.3 , and the $\left[\mathrm{Mn}^{2+}\right] /[\mathrm{Ga}]$ and $\left[\mathrm{Mn}^{3+}\right] /[\mathrm{Ga}]$ atomic ratios also increase, indicating the segregation of manganese on the surface. This fact is also supported by a decrease in the $[\mathrm{O}] /[\mathrm{Mn}$ + Ga] atomic ratio (Table 4). Fig. 6 sums up data on the [Mn]/ [Ga] atomic ratio in the subsurface layer as compared to the bulk characteristic - the lattice parameter of spinel in dependence on temperature; a correlation between the XRD and XPS data is seen.

Hence, the XPS data demonstrate that the treatment in argon or in hydrogen produces changes in the surface composition: manganese cations $\mathrm{Mn}^{2+}$ segregate, and the $[\mathrm{O}] /[\mathrm{Mn}+\mathrm{Ga}]$ atomic ratio decreases. It means that the removal of excess oxygen is accompanied not only by structural rearrangement but also by surface modification. At the same time, changes in the $\mathrm{Mn}^{2+} / \mathrm{Mn}^{3+}$ surface ratio that occur in the hydrogen atmosphere seem unusual: an increase in the concentration of $\mathrm{Mn}^{3+}$ and a decrease in $\mathrm{Mn}^{2+}$; however, they allow proposing a scheme of the initial step of reduction.

The mechanism of reduction. Changes in the $\mathrm{Mn}^{2+}$ and $\mathrm{Mn}^{3+}$ content, the $[\mathrm{Mn}] /[\mathrm{Ga}]$ atomic ratio on the sample surface, and bulk characteristics of the oxide revealed by XRD give grounds to suggest the mechanism of reduction in the first (initial) step. It should be reminded that the evolution of the surface composition at temperatures up to $450{ }^{\circ} \mathrm{C}$ is not accompanied by changes in the phase composition, and only a loss of excess oxygen is observed. Upon the treatment in hydrogen, oxygen is removed from the surface, and the surface $\mathrm{Mn}^{3+}$ cations are reduced to $\mathrm{Mn}^{2+}$. In spite of the observed segregation of manganese cations, the produced surface $\mathrm{Mn}^{2+}$ cations 'diffuse' into the bulk (most likely the hole is displaced), thus decreasing the relative content of $\mathrm{Mn}^{2+}$ on the surface upon reduction (Table 5). This process is implemented when the 'diffusion' rate of $\mathrm{Mn}^{2+}$ cations substantially exceeds the reduction rate. The emergence of $\mathrm{Mn}^{2+}$ cations into the bulk may testify to the formation of $\mathrm{MnO}$ clusters in the initial compound, which will pass to the MnO phase upon a further increase of temperature. The appearance of MnO clusters in the initial spinel structure indicates the substitution of the $\mathrm{Mn}^{2+}$ cations for $\mathrm{Mn}^{3+}$ and $\mathrm{Ga}^{3+}$ cations in octahedral positions or the filling of internode spaces. The ionic radius of $\mathrm{Mn}^{2+}$ in the octahedral environment, which is equal to $0.83 \AA$, is greater than the corresponding values for $\mathrm{Mn}^{3+}(0.58 \AA)$ and $\mathrm{Ga}^{3+}(0.62 \AA)$; this increases of the lattice parameter, $\mathrm{MnO}$ phase is released from the structure of initial oxide, and the relative content of $\mathrm{Mn}$ in spinel decreases to $\mathrm{MnGa}_{2} \mathrm{O}_{4}$.

Therefore, the hydrogen reduction of $\mathrm{Mn}-\mathrm{Ga}$ oxides with the spinel structure in the temperature range of $30-900{ }^{\circ} \mathrm{C}$ can be presented as follows. For the samples synthesized at 600$800{ }^{\circ} \mathrm{C}$, a two-step reduction of the oxide is observed, which is indicated by changes in the lattice parameter and by the TPR data. According to TG and TPR, the initial samples contain a certain amount of excess oxygen, $\mathrm{Mn}_{1.7} \mathrm{Ga}_{1.3} \mathrm{O}_{4+\delta}$, as compared to the stoichiometric content. In the first step, excess oxygen is removed, which is accompanied by an increase in the lattice parameter. The increase in the lattice parameter correlates with changes in the surface composition (the enrichment with manganese cations) revealed by XPS. In the second step, the $\mathrm{Mn}^{3+}$ cations are reduced to $\mathrm{Mn}^{2+}$, and manganese cations pass from the spinel structure to the $\mathrm{MnO}$ phase, thus changing the spinel composition from $\mathrm{Mn}_{1.7} \mathrm{Ga}_{1.3} \mathrm{O}_{4}$ to $\mathrm{MnGa}_{2} \mathrm{O}_{4}$ (Fig. 8).

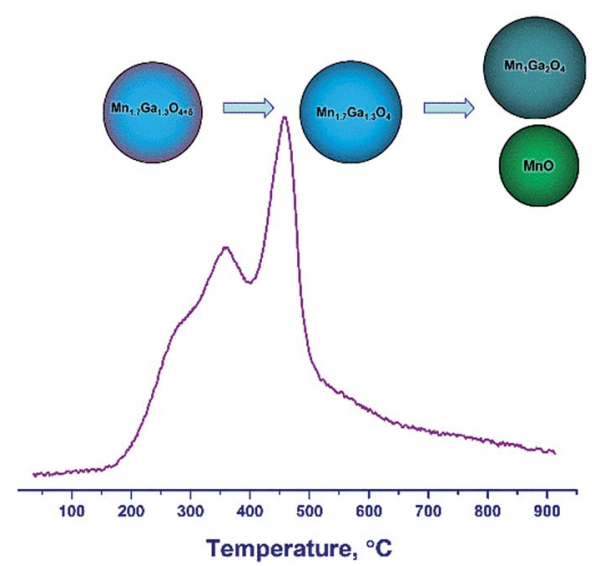

Fig. 8 A scheme of transformations upon reduction of $\mathrm{Mn}_{1.7} \mathrm{Ga}_{1.3} \mathrm{O}_{4+\delta}$ by hydrogen. 
For the high-temperature samples synthesized by calcination at $1000-1200{ }^{\circ} \mathrm{C}$ in argon, a single-step reduction of the oxide is observed. Initially, $\mathrm{Mn}$ cations are formally in the oxidation states $\mathrm{Mn}^{2+}$ (1.0) and $\mathrm{Mn}^{3+}(0.7)$ according to the formula $\mathrm{Mn}_{1}{ }^{2+} \mathrm{Mn}_{0.7}{ }^{3+} \mathrm{Ga}_{1.3}{ }^{3+} \mathrm{O}_{4}$; as a result of reduction, all $\mathrm{Mn}^{3+}$ cations turn into $\mathrm{Mn}^{2+}$. Probably, redistribution of $\mathrm{Mn}$ and Ga cations over tetrahedral and octahedral positions, respectively, with the formation of $\mathrm{Mn}_{1} \mathrm{Ga}_{2} \mathrm{O}_{4}$ spinel and the release of the $\mathrm{MnO}$ phase, becomes favorable.

\section{Conclusions}

A series of $\mathrm{Mn}_{1.7} \mathrm{Ga}_{1.3} \mathrm{O}_{4}$ mixed oxides synthesized by coprecipitation with subsequent calcination in argon at $600-1200{ }^{\circ} \mathrm{C}$ has been studied. TG and TPR studies revealed the presence of excess oxygen in the samples synthesized at $600-800{ }^{\circ} \mathrm{C}$. The loss of oxygen upon heating in argon (according to TG) and the presence of low-temperature peaks of hydrogen absorption (according to TPR) are observed for such oxides. An increase in the synthesis temperature to $1000-1200{ }^{\circ} \mathrm{C}$ results in the formation of mixed oxides not containing superstoichiometric oxygen. A correlation was found between the content of excess oxygen in the Mn-Ga oxides and their catalytic activity in the oxidation of CO.

The process of hydrogen reduction of the Mn-Ga oxides with the spinel structure has been studied. For the samples synthesized at $600-800{ }^{\circ} \mathrm{C}$, a two-step reduction of the oxide is observed. According to TPR and in situ XRD studies, excess oxygen is removed in the first step. An increase in the lattice parameter correlates with changes in the surface composition revealed by XPS, which indicates that changes in the bulk of the oxide modify the sample surface. The removal of excess oxygen upon reduction (which shows up as ancrease in the lattice parameter) is accompanied by surface enrichment with manganese cations. In the second step, $\mathrm{Mn}^{3+}$ cations are reduced to $\mathrm{Mn}^{2+}$ in the spinel structure with the release of the MnO phase.

\section{Conflicts of interest}

There are no conflicts to declare.

\section{Acknowledgements}

This work was conducted within the framework of the budget project \# AAAA-A17-117041710079-8 for Boreskov Institute of Catalysis. The authors thank V. A. Rogov for TPR- $\mathrm{H}_{2}$ measurements.

\section{Notes and references}

1 M. C. Álvarez-Galván, V. A. De La Peña O'Shea, J. L. G. Fierro and P. L. Arias, Catal. Commun., 2003, 4, 223.

2 C. Lahousse, A. Bernier, P. Grange, B. Delmon, P. Papaefthimiou, T. Ioannides and X. Verykios, J. Catal, 1998, 178, 214.
3 J. M. Gallardo-Amores, T. Armaroli, G. Ramis, E. Finocchio and G. Busca, Appl. Catal., B, 1999, 22, 249.

4 J. I. Gutiérrez-Ortiz, B. de Rivas, R. López-Fonseca, S. Martín and J. R. González-Velasco, Chemosphere, 2007, 68, 1004.

5 R. Craciun, B. Nentwick, K. Hadjiivanov and H. Knözinger, Appl. Catal., A, 2003, 243, 67.

6 H. Xu, N. Yan, Z. Qu, W. Liu, J. Mei, W. Huang and S. Zhao, Environ. Sci. Technol., 2017, 51, 8879.

7 F. Kapteijn, L. Singoredjo, A. Andreini and J. A. Moulijn, Appl. Catal., B, 1994, 3, 173.

8 B. Faure and P. Alphonse, Appl. Catal., B, 2015, 180, 715.

9 L. Yao, L. Zhang, Y. Liu, L. Tian, J. Xu, T. Liu, D. Liu and C. Wang, CrystEngComm, 2016, 18, 8887.

10 F. Cheng, J. Shen, B. Peng, Y. Pan, Z. Tao and J. Chen, Nat. Chem., 2011, 3, 79.

11 M. Mahmoud, T. A. Gad-Allah, K. M. El-Khatib and F. ElGohary, Bioresour. Technol., 2011, 102, 10459.

12 F. Conrad, M. Bauer, D. Sheptyakov, S. Weyeneth, D. Jaeger, K. Hametner, P. E. Car, J. Patscheider, D. Günther and G. R. Patzke, RSC Adv., 2012, 2, 3076.

13 O. A. Bulavchenko, T. N. Afonasenko, P. G. Tsyrul'nikov and S. V. Tsybulya, Appl. Catal., A, 2013, 459, 73.

14 J. Ziółkowski, A. M. Maltha, H. Kist, E. J. Grootendorst, H. J. M. De Groot and V. Ponec, J. Catal., 1996, 160, 148.

15 M. Li, Q. Gao, T. Wang, Y. S. Gong, B. Han, K. S. Xia and C. G. Zhou, Mater. Des., 2016, 97, 341.

16 A. Maltha, H. F. Kist, B. Brunet, J. Ziolkowski, H. Onishi, Y. Iwasawa and V. Ponec, J. Catal., 1994, 149, 356.

17 O. S. Venediktova, O. A. Bulavchenko, T. N. Afonasenko, P. G. Tsyrul'nikov, Z. S. Vinokurov, Y. A. Chesalov, et al., J. Alloys Compd., 2017, 725, 496.

18 ICDD, PDF-4+ Database, ed. S. Kabekkodu, International Centre for Diffraction Data, Newtown Square, PA, USA, 2012. 19 P. Scherre, Math. Phys. Kl, 1918, 98.

20 N. Fairley, http://www.casaxps.com.

21 H. Fan, G. Wang and L. Hu, Solid State Sci., 2009, 11, 2065.

22 K. Bao, L. Wang, J. Yan, H. Sun, R. Guo and Y. Wu, J. Alloys Compd., 2013, 552, 26.

23 L. Qin, C. Xue, Y. Duan and L. Shi, Phys. B, 2009, 404, 190.

24 E. Regan, T. Groutso, J. B. Metson, R. Steiner, B. Ammundsen, D. Hassell and P. Pickering, Surf. Interface Anal., 1999, 1064.

25 M. Oku, K. Hirokawa and S. Ikeda, J. Electron Spectrosc. Relat. Phenom., 1975, 7, 465.

26 V. D. Castro and G. Polzonetti, J. Electron Spectrosc. Relat. Phenom., 1989, 48, 117.

27 J. F. Bondi, K. D. Oyler, X. Ke, P. Schiffer and R. E. Schaak, J. Am. Chem. Soc., 2008, 131, 9144.

28 Y.-F. Han, F. Chen, Z. Zhong, K. Ramesh, L. Chen and E. Widjaja, J. Phys. Chem. B, 2006, 110, 24450.

29 Y.-F. Han, L. Chen, K. Ramesh, Z. Zhong, F. Chen, J. Chin and H. Mook, Catal. Today, 2008, 131, 35.

30 X. Yang, X. Wang, G. Zhang, J. Zheng, T. Wang, X. Liu, C. Shu, L. Jiang and C. Wang, Int. J. Hydrogen Energy, 2012, 37, 11167.

31 K. Ramesh, L. Chen, F. Chen, Y. Liu, Z. Wang and Y.-F. Han, Catal. Today, 2008, 131, 477. 
32 Y. Liu, J. Li, W. Li, Y. Li, Q. Chen and F. Zhan, J. Power Sources, 2015, 299, 492.

33 W. Kong, B. Gao, C. Jiang and A. Chang, J. Alloys Compd., 2015, 650, 305.

34 L. Zhang, Z. Tang, S. Wang, D. Ding, M. Chen and H. Wan, Surf. Sci., 2012, 606, 1507.

35 P. R. Jadhav, M. P. Suryawanshi, D. S. Dalavi, D. S. Patil, E. A. Jo, S. S. Kolekar, A. A. Wali, M. M. Karanjkar, J.-H. Kim and P. S. Patil, Electrochim. Acta, 2015, 176, 523.
36 M. A. Kostowskyj, D. W. Kirk and S. J. Thorpe, Int. J. Hydrogen Energy, 2010, 35, 5666.

37 T. Hishida, K. Ohbayashi and T. Saitoh, J. Appl. Phys., 2013, 113, 043710.

38 X. Feng and D. F. Cox, Surf. Sci., 2016, 645, 23.

39 E. R. Stobbe, B. A. De Boer and J. W. Geus, Catal. Today, 1999, 47(1-4), 161-167.

40 L. Christel, A. Pierre and D. A. M. R. Abel, Thermochim. Acta, 1997, 306, 51.

41 L. Zhang and Y. Wu, J. Nanomater., 2013, 2013, 640940. 